\title{
IMPLEMENTASI PEMBELAJARAN PENDIDIKAN AGAMA ISLAM DI SEKOLAH DASAR (SD) MUHAMMADIYAH METRO PUSAT
}

\author{
Oleh. \\ Noormawanti \\ Universitas Muhammadiyah Metro \\ noormawanti13@gmail.com
}

\begin{abstract}
This study discusses the Implementation of Islamic Education Learning. The focus of this study is about: 1) How is the planning, implementation and evaluation of the implementation of learning in Islamic Religious Education at the Muhammadiyah Metro Central Elementary School; 2) What are the supporting and inhibiting factors in the implementation of learning Islamic Education at the Muhammadiyah Metro Central Elementary School. The purpose of this study is to describe: Implementation of Islamic Education Learning in the Muhammadiyah Metro Central Elementary School.

The design of this study is to use a qualitative approach with a descriptive research model. So that this research is a qualitative descriptive study. The data collection technique uses observation and interview methods. To make it easier to explain the data, categorization and organization of data is done with a coding system. The research informants were obtained by snowball sampling technique, then testing the validity of the data was done using the triangulation method. In data processing and data analysis carried out during and after conducting research.

The results showed that the Implementation of Islamic Education Learning in Muhammadiyah Metro Pusat Elementary School (SD) in the planning process was realized in a Learning Implementation Plan (RPP), which was given a special time by the school to prepare learning tools which included: syllabus formulation, educational calendar, annual programs, semester programs, teaching materials up to remedial activities and endorsed by the school supervision team. In the implementation of Islamic Education Learning in SD Muhammadiyah Metro the Center for Islamic Education Teachers refers to one component of the learning strategy, namely the component of the learning method. The method used by Islamic Education Teachers at Elementary School Muhammadiyah Metro Pusat is the lecture method, discussion method, training method and demonstration method. Evaluations used include: 1) UTS (Semster Middle Examination), 2) Semester Exams, 3) Practice Exams. It is also influenced by supporting and inhibiting factors. Supporting factors include: adequate school infrastructure, professional teachers, character development activities, while the inhibiting factors are limited learning resources and low student motivation.
\end{abstract}

Keywords: Implementation, learning, Islamic Education. 


\begin{abstract}
Abstrak
Penelitian ini membahas Implementasi Pembelajaran Pendidikan Agama Islam. Fokus penelitian ini adalah tentang: 1) Bagaimana perencanaan, pelaksanaan dan evaluasi pelaksanaan pembelajaran Pendidikan Agama Islam di SDN Muhammadiyah Metro; 2) Apa saja faktor pendukung dan penghambat dalam pelaksanaan pembelajaran Pendidikan Agama Islam di SDN Muhammadiyah Metro. Tujuan penelitian ini adalah untuk mendeskripsikan: Implementasi Pembelajaran Pendidikan Agama Islam di SDN Muhammadiyah Metro.

Desain penelitian ini adalah menggunakan pendekatan kualitatif dengan model penelitian deskriptif. Sehingga penelitian ini adalah penelitian deskriptif kualitatif. Teknik pengumpulan data menggunakan metode observasi dan wawancara. Untuk membuatnya lebih mudah untuk menjelaskan data, kategorisasi dan pengorganisasian data dilakukan dengan sistem pengkodean. Informan penelitian diperoleh dengan teknik snowball sampling, kemudian pengujian validitas data dilakukan dengan menggunakan metode triangulasi. Dalam pengolahan data dan analisis data dilakukan selama dan setelah melakukan penelitian.

Hasil penelitian menunjukkan bahwa Implementasi Pembelajaran Pendidikan Agama Islam di Sekolah Dasar Muhammadiyah Metro Pusat (SD) dalam proses perencanaan diwujudkan dalam Rencana Pelaksanaan Pembelajaran (RPP), yang diberikan waktu khusus oleh sekolah untuk menyiapkan alat belajar yang meliputi: perumusan silabus, kalender pendidikan, program tahunan, program semester, bahan ajar hingga kegiatan perbaikan dan didukung oleh tim pengawasan sekolah. Dalam pelaksanaan Pembelajaran Pendidikan Agama Islam di SD Muhammadiyah Metro, Pusat Pendidikan Agama Islam mengacu pada satu komponen strategi pembelajaran, yaitu komponen metode pembelajaran. Metode yang digunakan oleh Guru Pendidikan Agama Islam di Sekolah Dasar Muhammadiyah Metro Pusat adalah metode ceramah, metode diskusi, metode pelatihan dan metode demonstrasi. Evaluasi yang digunakan meliputi: 1) UTS (Semster Middle Examination), 2) Ujian Semester, 3) Ujian Praktek. Ini juga dipengaruhi oleh faktor pendukung dan penghambat. Faktor pendukung meliputi: infrastruktur sekolah yang memadai, guru profesional, kegiatan pengembangan karakter, sedangkan faktor penghambatnya adalah sumber belajar yang terbatas dan motivasi siswa yang rendah.
\end{abstract}

\title{
Kata Kunci: Implementasi, Pembelajaran, Pendidikan Islam
}

\section{A. PENDAHULUAN}

Pendidikan Islam sebagai suatu proses pengembangan potensi kreatifitas peserta didik, bertujuan untuk mewujudkan manusia yang beriman dan bertakwa kepada Allah SWT, cerdas, terampil, memiliki etos kerja yang tinggi, berbudi pekerti luhur, mandiri dan bertanggung jawab terhadap dirinya, bangsa dan negara serta agama.

Secara umum, pendidikan
agama Islam bertujuan untuk
meningkatkan keimanan, pemahaman,


penghayatan, dan pengamalan peserta didik tentang Agama Islam, sehingga menjadi manusia muslim yang beriman dan bertakwa kepada Allah SWT serta berakhlak mulia dalam kehidupan pribadi, bermasyarakat, berbangsa dan bernegara. Dari tujuan tersebut dapat ditarik beberapa dimensi yang hendak ditingkatkan dan dituju oleh kegiatan pembelajaran pendidikan Agama Islam, yaitu: (1) dimensi keimanan peserta didik terhadap ajaran agama Islam, (2) dimensi pemahaman atau penalaran (intelektual) serta keilmuan peserta didik terhadap ajaran Agama Islam, (3) dimensi penghayatan atau pengalaman batin yang dirasakan peserta didik dalam menjalankan ajaran Islam, (4) dimensi pengamalannya, dalam arti bagaimana ajaran Islam yang diimani, difahami dan dihayati atau di internalisasi oleh peserta didik itu mampu menumbuhkan motivasi dalam dirinya untuk menggerakkan, mengamalkan, dan menaati ajaran agama dan nilai-nilainya dalam kehidupan peribadi, sebagai manusia yang beriman dan bertakwa kepada Allah SWT. Serta mengaktualisasikan dan merealisasikannya dalam kehidupan bermasyarakat, berbangsa dan bernegara. ${ }^{1}$

Pendidikan agama Islam pada kenyataannya belumlah demikian, pendidikan pada umumnya masih saja mengedepankan aspek kognitif siswa saja tidak terkecuali pendidikan Islam. Di mana seorang siswa masih dituntut

1 Muhaimin, "Paradigma Pendidikan Islam Upaya Mengefektifkan Pendidikan Agama Islam Di Sekolah", Bandung : PT Remaja Rosda Karya , Cet-1, 2001, h. 78.

untuk bisa mendapatkan poin/ nilai yang tinggi pada mata pelajaran tersebut dan akhirnya mengesampingkan aspek afeksinya, padahal itulah yang terpenting dalam sebuah proses pembelajaran, khususnya Agama Islam.

Sejalan dengan pengertian di atas, arah pendidikan Islam adalah menuju terbentuknya peserta didik yang mempunyai kemampuan kognitif intelektual yang cerdas. Dengan kecerdasannya ia dapat melakukan sesuatu yang baik menurut Islam untuk kemaslahatan hidup bersama. Hidup bersama dalam artian mengetahui dan menghargai adanya perbedaan serta menghargainya sebagai milik seluruh umat manusia bukan atas dasar untuk memecah belah kehidupan. Selain dari kemampuan tersebut, ada kemampuan lain yang harus dikembangkan dalam pendidikan Islam adalah aspek afeksi dan psikomotorik.

Kognitif, yakni pengetahuan dan pemahaman siswa terhadap ajaran dan nilai-nilai yang terkandung dalam ajaran Islam, dimana ranah kognitif (Cognitive domain), menurut Bloom dan kawan-kawan meliputi: pengetahuan, pemahaman, penerapan, analisis, sintesis dan evaluasi. Untuk selanjutnya menuju ketahapan afeksi, yakni terjadinya proses internalisasi ajaran dan nilai agama ke dalam diri siswa, dalam arti menghayati dan meyakininya, ranah afektif (affective domain) menurut Kratwohl. Bloom dan kawan-kawan adalah meliputi: penerimaan, partisipasi, penilaian, organisasi dan pembentukan pola 
hidup. Tahapan afeksi ini terkait erat dengan kognitif, artinya penghayatan dan keyakinan siswa menjadi kokoh jika dilandasi oleh pengetahuan dan pemahamannya terhadap ajaran dan nilai agama Islam. Melalui tahapan afeksi tersebut diharapkan dapat tumbuh motivasi dalam dirinya dan tergerak untuk mengamalkan dan menaati ajaran Islam sebagai tahapan psikomotorik yang telah diinternalisasikan dalam dirinya, ranah Psikomotorik (pcyhomotorik domain) menurut Simpson adalah: persepsi, kesiapan, gerakan terbimbing, gerakan yang terbiasa, gerakan yang kompleks, penyesuaian dan kreativitas. ${ }^{2}$ Dengan demikian akan terbentuk manusia muslim yang beriman, bertakwa dan berakhlak mulia.

Ranah tujuan pendidikan Islam sebenarnya lebih luas lagi dari ranah di atas, di samping kognitif, afektif, dan psikomotorik, juga meliputi ranah konatif dan performance. Konatif, berhubungan dengan motivasi atau dorongan dari dalam atau disebut niat, sebagai titik tolak peserta didik untuk melakukan sesuatu. Sedangkan performance adalah kualitas yang dilakukan seseorang, misalnya ranah tujuan ibadah shalat. Ranah kognitifnya yaitu pengetahuan tentang shalat, ranah konatifnya adalah niat (motivasi) melaksanakan shalat, ranah psikomotornya pengamalan shalat, ranah afektifnya pengaruh shalat terhadap mental, dan ranah

2 Ramayulis Dan Samsul Nizar, "Filsafat Pendidikan Islam", Jakarta: Kalam Mulia, 2009, h. 132. performancenya, khusu', tawadhu', dan tuma'ninah. ${ }^{3}$

Pendidikan Islam berfungsi mengembangkan seluruh potensi peserta didik secara bertahap. Potensi yang dikembangkan meliputi potensi beragama, intelek, sosial, ekonomi, seni, pesamaan, keadilan, pengembangan, harga diri, cinta tanah air serta memiliki wawasan ilmu pengetahaun, skill, teknologi dan punya bekal iman taqwa ${ }^{4}$. Tujuan pengembangannya ada yang bersifat individual, yaitu berkaitan dengan individu-individu yang menyangkut tingkah laku, aktivitas dan kehidupannya di dunia dan akhirat. Ada yang bersifat sosial yang berkaitan dengan kehidupan masyarakat secara keseluruhan, memperkaya pengalaman dan kemajuan yang diinginkan, dan ada pula yang bersifat professional untuk memperoleh ilmu, seni, profesi, dan suatu aktivitas diantara aktivitasaktivitas masyarakat. ${ }^{5}$

Pembelajaran pendidikan Agama Islam pada umumnya lebih menekankan pengetahuan tentang sikap yang terkesan normatif, kaku dan kurang menarik. Guru sering menempatkan diri sebagai pendakwah dengan memberi petunjuk, perintah dan aturan yang membuat peserta didik

\footnotetext{
${ }^{3}$ Ibid; h, 133.

4 M.Ihsan Dacholfany, Inisiasi Strategi Manajemen Lembaga Pendidikan Islam Dalam Meningkatkan Mutu Sumber Daya Manusia Islam di Indonesia Dalam menghadapi Era Globalisasi, Jurnal AtTajdid, Volume 1, No.1 Januari-Juni, 2017, h.1

5 Omar Muhammad al-Toumy alSyaibany, "Falsafah Pendidikan Islam", Jakarta: Bulan Bintang, 1979, h.399.
} 
jenuh dan bosan. Guru juga jarang memberikan sebuah keteladanan dengan sikap dan perilaku yang nyata.

Beberapa alasan untuk memilih judul ini adalah, dikarenakan pada tingkat sekolah dasar yang mestinya ditekankan pada tujuan pendidikannya adalah pada ranah afeksi, di mana penanaman nilai-nilai pengetahuan yang dalam hal ini pengetahuan Agama Islam haruslah ditanamkan melalui proses pembiasaan, karena dengan proses ini siswa akan lebih mudah menghayati dan akan lebih mudah mengamalkannya pada kehidupan kesehariannya, maka sudah seharusnya seorang guru menggunakan metode yang tepat serta bervariasi dalam menyampaikan materi pelajaran disertai dengan penggunaan contohcontohnya, sehingga yang dilakukan dengan teratur dan terprogram untuk mencapai tujuan ${ }^{6}$.

Berdasarkan pemikiran tersebut, maka perlu adanya penelitian tentang implementasi pembelajaran Pendidikan Agama Islam pada Sekolah Dasar, yang meliputi apa saja metode pembelajaran yang digunakan, bagaimana proses pembelajarannya dan bagaimana evaluasinya serta faktorfaktor pendukung dan penghambat bagi pelaksanaanya, dalam rangka mencapai tujuan pendidikan yang diharapkan. Penelitian ini diberi judul “ Implementasi Pembelajaran Pendidikan

${ }^{6}$ M.Ihsan Dacholfany, Inisiasi Strategi Manajemen Lembaga Pendidikan Islam Dalam Meningkatkan Mutu Sumber Daya Manusia Islam di Indonesia Dalam menghadapi Era Globalisasi, Jurnal At-Tajdid, Volume 1, No.1 Januari-Juni, 2017 h.4
Agama Islam di Sekolah Dasar (SD) Muhammadiyah Metro Pusat"

Berdasarkan latar belakang masalah dan proses pembelajaran merupakan suatu jalan untuk mencapai tujuan pembelajaran. Untuk mencapai tujuan pembelajaran diperlukan proses yang panjang, maka dapat dikemukakan rumusan masalahnya, yaitu:

1. Bagaimana perencanaan, pelaksanaan dan evaluasi dalam implementasi pembelajaran pendidikan agama Islam?

2. Apa faktor pendukung dan penghambat dalam implementasi pembelajaran pendidikan agama Islam?

\section{B. METODE PENELITIAN}

Jenis penelitian ini adalah penelitian deskriptif analisis kualitatif. Menurut Moleong penelitian kualitatif itu berakar pada latar alamiah sebagai keutuhan, mengandalkan manusia sebagai alat penelitian, memanfaatkan metode kualitatif, mengadakan analisis data secara induktif, mengarahkan sasaran penelitiannya pada usaha menemukan teori-teori dasar, bersifat deskriptif, lebih mementingkan proses dari pada hasil, membatasi studi dengan fokus, memiliki seperangkat kriteria untuk memeriksa keabsahan data, rancangan penelitiannya bersifat sementara, dan hasil penelitiannya disepakati oleh kedua belah pihak yakni peneliti dan subyek penelitian. ${ }^{7}$

\section{${ }^{7}$ Lexy J. Moleong, Metodologi}

Penelitian Kualitatif, Bandung: Remaja Rosda Karya, Cet-27, 2010, h. 44. 
Pendapat

mengemukakan bahwa metode penelitian kualitatif adalah metode penelitian yang digunakan untuk meneliti pada kondisi obyek alamiah, (sebagai lawannya adalah eksperimen) dimana peneliti adalah sebagai instrument kunci, teknik pengumpulan data dilakukan secara triangulasi (gabungan), analisis data bersifat induktif, dan hasil penelitian kualitatif lebih menekankan makna dari pada generalisasi. $^{8}$

Untuk mengumpulkan data kualitatif, maka digunakan beberapa teknik, yaitu: Observasi adalah teknik pengumpulan data yang dilakukan dengan mengamati gejala-gejala atau peristiwa yang terjadi pada obyek penelitian. 9, dan wawancara Wawancara adalah bentuk komunikasi langsung antara peneliti dengan responden. Komunikasi berlangsung dalam bentuk tanya jawab dalam hubungan tatap muka, sehingga gerak dan mimik responden merupakan pola media yang melengkapi kata-kata secara verbal. ${ }^{10}$

\section{LANDASAN TEORI}

\section{a. Implementasi Pembelajaran}

1. Pengertian Pembelajaran Pembelajaran terkait dengan bagaimana (how to)

8 Sugiyono, Memahami Penelitian Kualitatif, Bandung: Alfabeta, Cet-1, 2005, h. 1.

9 Sutrisna Hadi, Metodologi Research, Yogyakarta: Fakultas Psikologi UGM, Cet-2, 1980, h. 136.

10 W. Gulo, Metodologi Penelitian, Jakarta: PT Gramedia Widia Sarana, Cet-1, 2002, h.119. membelajarkan siswa atau bagaimana membuat siswa dapat belajar dengan mudah dan terdorong oleh kemauannya sendiri untuk mempelajari apa (what to) yang teraktualisasikan dalam kurikulum sebagai kebutuhan (needs) peserta didik. $^{11}$

\begin{tabular}{|c|c|}
\hline & \\
\hline $\begin{array}{l}\text { Pada } \\
\text { engatakan, } \\
\text { embelaiaran }\end{array}$ & $\begin{array}{l}\text { sumber } \\
\text { bahwa } \\
\text { adalah: }\end{array}$ \\
\hline
\end{tabular}
pembelajaran berasal dari kata belajar mendapat awalan "pem" dan akhiran "an" menunjukkan bahwa ada unsur dari luar (eksternal) yang bersifat "intervensi" agar terjadi proses belajar, jadi pembelajaran merupakan upaya yang dilakukan oleh faktor eksternal agar terjadi proses belajar pada diri individu yang belajar. Pembelajaran mengandung makna setiap kegiatan yang dirancang untuk membantu individu mempelajari sesuatu kecakapan tertentu, oleh sebab itu, dalam pembelajaran pemahaman karakteristik internal individu yang belajar menjadi penting. Proses pembelajaran merupakan aspek yang terintegrasi dari proses pendidikan. ${ }^{12}$

$$
\text { Aspek terpenting dari }
$$
pembelajaran adalah membelajarkan siswa. Bukan memberikan pelajaran kepada siswa. Pembelajaran adalah proses pembelajaran antara guru dan murid. Kegiatan ini di dalam dunia pendidikan dikenal dengan istilah PBM (Proses Belajar Mengajar). Di dalam

11 Muhaimin, Paradigma Pendidikan Islam, Bandung: Remaja Rosda Karya, Cet-2, 2002, h. 145.

12 Karwono, dan Heni Mularsih, Belajar dan Pembelajaran, serta pemanfaatan sumber belajar, Jakarta: Rajawali Pers, 2012., h. 20. 
PBM ini terkandung dua hal pokok yaitu kegiatan guru dalam mengajar, dalam arti membelajarkan siswa dan kegiatan siswa dalam belajar. ${ }^{13}$

Dalam UU No. 20 Tahun 2003 tentang Sisdiknas Pasal 1 Ayat 20, yang dikutip oleh Bambang Warsita dalam bukunya yang berjudul: Teknologi Pembelajaran Landasan dan Aplikasinya, menyatakan pembelajaran adalah proses interaksi peserta didik dengan pendidik dan sumber belajar pada suatu lingkungan belajar. Oleh karena itu, ada lima jenis interaksi yang dapat berlangsung dalam proses belajar dan pembelajaran, yaitu: 1) interaksi antara pendidik dengan peserta didik; 2) interaksi antarsesama peserta didik atau antarsejawat; 3) interaksi peserta didik dengan narasumber; 4) interaksi peserta didik bersama pendidik dengan sumber belajar yang sengaja dikembangkan; 5) interaksi peserta didik bersama pendidik dengan lingkungan sosial dan alam. $^{14}$

Interaksi yang terjadi antara siswa dengan lingkungan belajarnya, baik dengan guru, teman-temannya, alat, media pembelajaran, dan sumbersumber belajar yang lain, sedangkan ciri yang lain dalam pembelajaran adalah berkaitan dengan komponenkomponen pembelajaran itu sendiri.

1. Komponen-komponen Pembelajaran

13 Muhaimin, Abd. Ghofir dan Nur Ali Rahman, Strategi Belajar Mengajar, Surabaya : CV Citra Media, 1996, h. 178.

14 Bambang Warsita, Teknologi Pembelajaran Landasan dan Aplikasinya, Jakarta: Rineka Cipta, 2008, h. 85-86.
Terdapat beberapa komponenkomponen dalam proses pembelajaran, antara lain adalah:

a. Tujuan,

b. Sumber Belajar,

c. Strategi Pembelajaran,

d. Media Pembelajaran,

e. Evaluasi Pembelajaran, ${ }^{15}$

2. Pendekatan Pembelajaran

Pendekatan merupakan titik tolak atau sudut pandang kita terhadap proses pembelajaran.

a. Pendekatan Pembelajaran Berorientasi Pada Guru (teacher centered approaches).

b. Pendekatan Pembelajaran Berorientasi pada Siswa (student centered approach). ${ }^{16}$

3. Perencanaan Proses Pembelajaran Perencanaan proses pembelajaran meliputi Silabus dan Rencana Pelaksanaan Pembelajaran (RPP) yang memuat identitas mata pelajaran, Standar Kompetensi (SK), Kompetensi Dasar (KD), indikator pencapaian kompetensi, tujuan pembelajaran, materi ajar, alokasi waktu, metode pembelajaran, kegiatan pembelajaran, penilaian hasil belajar dan sumber belajar.

4. Profesionalsime Guru

Secara etimologi, istilah profesi berasal dari bahasa Inggris

15 Rusman dkk, Pembelajaran Berbasis Teknologi Informasi dan Komunikasi, mengembangkan profesionalitas guru, Bandung : PT Raja Grafindo Persada, Cet-2, 2012, h. 42-43.

${ }^{16}$ Ibid; h. 45-46. 
yaitu profession atau bahasa latin, profecus, yang artinya mengakui, adanya pengakuan, menyatakan mampu atau ahli dalam melakukan suatu pekerjaan. Sedangkan secara terminologi, profesi berarti suatu pekerjaan yang mempersyaratkan pendidikan tinggi bagi pelakunya yang ditekankan pada pekerjaan mental, yaitu adanya persyaratan pengetahuan teoritis sebagai instrumen untuk melakukan perbuatan praktis, bukan perbuatan manual. ${ }^{17}$

Pada sumber yang lain dikatakan bahwa profesi secara umum diartikan sebagai suatu pekerjaan yang memerlukan pendidikan lanjut di dalam science dan teknologi yang digunakan sebagai perangkat dasar untuk diimplementasikan dalam berbagai kegiatan yang bermanfaat. Dalam aplikasinya, menyangkut aspekaspek yang lebih besifat mental daripada yang bersifat manual work. Pekerjaan profesional akan senantiasa menggunakan teknik dan prosedur yang berpijak pada landasan intelektual yang harus dipelajari secara sengaja, terencana dan kemudian dipergunakan demi kemaslahatan orang lain. ${ }^{18}$

Profesionalisme berasal dari profession yang berarti pekerjaan. Profession mengandung arti yang sama dengan kata occupation atau pekerjaan yang memerlukan

17 Ibid; h.30.

18 Sardiman, Interaksi dan Motivasi Belajar Mengajar, Jakarta: Rajawali Pers, Cet21, 2012, h. 133. keahlian yang diperoleh melalui pendidikan atau latihan khusus. Pengertian profesionalisme adalah suatu pandangan terhadap keahlian tertentu yang diperlukan dalam pekerjaan tertentu, yang mana keahlian itu hanya diperoleh melalui pendidikan khusus atau latihan khusus. Profesionalisme Guru merupakan kondisi, arah, nilai, tujuan dan kualitas suatu keahlian dan kewenangan dalam bidang pendidikan dan pembelajaran yang berkaitan dengan pekerjaan seseorang yang menjadi mata pencaharian. Sementara itu, guru yang profesional adalah guru yang memiliki kompetensi yang dipersyaratkan untuk melakukan tugas pendidikan dan pembelajaran, ${ }^{19}$ dengan harapan guru dapat bekerja produktif untuk mendapatkan hasil pembelajaran yang berkualitas ${ }^{20}$.

Pada sumber yang lain dikatakan bahwa guru profesional adalah orang yang memiliki kemampuan dan keahlian khusus dalam bidang keguruan sehingga ia mampu melakukan tugas dan

\footnotetext{
${ }^{19}$ Rusman, Belajar dan Pembelajaran Berbasis Komputer, Mengembalikan Profesionalisme Guru Abad 21, h. 33.

20 Rubiyah Astuti dan M. Ihsan Dacholfany, Pengaruh Supervisi Pengawas sekolah dan Kepemimpinan Kepala Sekolah Terhadap Kinerja Guru SMP Di Kota Metro Lampung, Jurnal Lentera Pendidikan Pusat Penelitian LPPM UM metro, Vo,1, No.2 Desember 2016, h.25
} 
fungsinya sebagai guru dengan kemampuan yang maksimal. ${ }^{21}$

\section{A. Pendidikan Agama Islam (PAI)}

1. Pengertian Pendidikan Agama Islam

Pendidikan adalah proses penyiapan generasi muda untuk menjalankan kehidupan dan memenuhi tujuan hidupnya secara lebih efektif dan efisien yang di dalamnya tercakup transfer ilmu, tranformasi nilai dan pembentukan kepribadian. ${ }^{22}$ Kata "pendidikan" di sini dirangkai dengan kata "Agama Islam", sehingga Pendidikan Agama Islam berarti pendidikan mengenai seluruh aspek Agama Islam secara luas. Definisi Pendidikan Agama Islam menurut ahli diantaranya adalah : Pendidikan Agama Islam adalah usaha berupa bimbingan dan asuhan terhadap peserta didik agar kelak setelah selesai pendidikannya dapat memahami dan mengamalkan ajaran Agama Islam serta menjadikannya sebagai pandangan hidup (way of life). ${ }^{23}$

Pada sumber yang lain dikatakan bahwa Pendidikan Agama Islam adalah usaha sadar untuk menyiapkan siswa dalam meyakini, memhami, menghayati, dan mengamalkan Agama Islam melalui

21 M. Uzer Usman, Menjadi Guru Profesional, Bandung: Remaja Rosda Karya, 1995, h. 15.

22 Azyumardi Azra, Pendidikan Islam, Tradisi Dan Modernisasi Menuju Millennium Baru, Jakarta: Logos, 1999, h.3. 23 Zakiah Darajad dkk, Ilmu Pendidikan Islam, Jakarta: Bumi Aksara, 2008, h. 86 . kegiatan bimbingan, pengajaran, dan atau latihan dengan memperhatikan tuntutan untuk menghormati agama lain dalam hubungan kerukunan antar umat beragama dalam masyarakat untuk mewujudkan persatuan nasional. ${ }^{24}$

2. Dasar-Dasar Pendidikan Agama Islam

Dasar adalah sesuatu yang sangat fundamental dalam sebuah bangunan, begitu juga dengan pendidikan Islam, ia juga memiliki dasar yang dijadikan sebagai sumber kekuatan dan kekokohan dari pendidikan Islam itu sendiri, dasardasar tersebut antara lain adalah:

a. Dasar Ideal Pendidikan Islam

1. Al-Qur'an, umat Islam dianugrahkan Allah suatu kitab suci Al-Qur'an yang lengkap dengan segala petunjuk dan meliputi seluruh aspek kehidupan dan bersifat universal. Sehingga tentu dasar pendidikan mereka adalah bersumber kepada falsafah hidup yang berdasarkan kepada Al-Qur'an. Nabi Muhammad SAW sebagai pendidik pertama. Kedudukan Al-Qur'an sebagai sumber pokok pendidikan Islam dapat dipahami dari firman Allah, yang artinya:

Artinya: "Dan Kami tidak menurunkan kepadamu AlKitab (Al Quran) ini, melainkan agar kamu dapat

24 Muhaimin, Paradigma Pendidikan Islam, Upaya Mengefektifkan Pendidikan Agama Islam Di Sekolah, Bandung : PT Remaja Rosda Karya, Cet-1, 2001, h. 75-76. 
menjelaskan kepada mereka

apa yang mereka

perselisihkan itu dan

menjadi petunjuk dan rahmat

bagi kaum yang beriman". (

QS. An-Nahl (16): 64). ${ }^{25}$

2. Sunnah, dasar yang kedua setelah Al-Qur'an adalah sunnah Rasulullah. Amalan yang dikerjakan oleh Rasululah SAW dalam proses perubahan hidup sehari-hari menjadi sumber utama pendidikan Islam setelah AlQur'an.

3. Perkataan, Perbuatan dan Sikap para Sahabat, sikap dan perbuatan para sahabat serta ijtihad para ulama disebut sebagai dasar tambahan. Dasar tambahan ini dapat dipakai selama tidak bertentangan dengan dasar pokok. Hal ini dapat dilihat dari berbagai kebijakan pendidikan yang dilakukan para sahabat. Pada masa Khulafa Al-Rasyidin misalnya sumber sumber pendidikan dalam Islam sudah mengalami perkembangan. Selain Al-Qur'an dan sunnah, digunakan juga perkataan, sikap dan perbuatan para sahabat sebagai dasar pendidikan yang dibangun. Hal ini dijelaskan dalam firman Allah berikut ini:
Kemudian dalam surat At-Taubah ayat 119 yang artinya :

Artinya: "Hai orang-orang yang beriman bertakwalah kepada Allah, dan hendaklah kamu bersama orang-orang yang benar"..(QS. AtTaubah: 119). ${ }^{26}$

4. Ijtihad, adalah penggunaan akal fikiran oleh para foqoha' Islam untuk menetapkan suatu hokum yang belum ada ketetapannya dalam Al-Qur'an dan Hadis dengan syara-syarat tertentu. Ijtihad ini dapat dilakukan dengan ijma, qiyas, istihsan, masaliul mursalah dan lain-lain. 27

3. Aspek-aspek Pendidikan Agama Islam:

a. Aspek Aqidah

\begin{tabular}{lrr}
\multicolumn{2}{c}{ Imam } & Ghazali \\
menjelaskan & kepada & kita \\
begaimana cara menanamkan & man \\
aqidah, sebgaimana dikutip oleh \\
Muhammad & Suwaid & dalam \\
bukunya: & Mendidik & Anak \\
Bersama & Nabi. & Beliau
\end{tabular}
mengatakan: "Cara menanamkan keyakinan ini bukanlah dengan mengajarkan keterampilan berdebat dan berargumentasi, akan tetapi caranya adalah menyibukkan diri dengan membaca Al-Qur'an dan

${ }^{26}$ Ibid; h. 206.

27 Ramayulis dan Syamsul Nizar, Filsafat Pendidikan Islam, h. 108-112. 
tafsirnya, membaca hadits dan dan makna-maknanya serta sibuk dengan tugas-tugas ibadah. Dengan demikian kepercayaan dan keyakinan anak akan terus bertambah kokoh sejalan dengan semakin seringnya dalil-dalil AlQur'an yang didengar olehnya dan juga sesuai dengan berbagai bukti dan Al-Hadis Nabi yang ia telaah dari berbagai faedah yang bisa ia petik. Ini ditambah lagi oleh cahaya-cahaya ibadah dan amalan-amalan yang dikerjakannya yang akan semakin memperkuat itu semua. ${ }^{28}$

b. Aspek Ibadah

Pembinaan ibadah merupakan penyepurnaan dari pembinaan aqidah. Menurut pendapat Said Ramadhan Al Buthi ia mengatakan "Agar aqidah anak tertanam kuat didalam jiwanya, ia harus disiram dengan air ibadah dalam berbagai bentuk dan macamnya sehingga aqidahnya akan tumbuh dengan kokoh, dan juga tegar menghadapi terpaan badai dan cobaan kehidupan". ${ }^{29}$

c. Aspek Akhlak

Secara moralitas, membaguskan akhlak merupakan salah satu usaha untuk membentuk akhlak manusia agar menjadi baik, memiliki pribadi yang bermoral, berbudi pekerti yang luhur dan bersusila, berarti

28 Muhammad Suwaid, Mendidik Anak Bersama Nabi, Jakarta: Pustaka Arafah, Cet-2, 2004, h.113.

${ }^{29}$ Ibid;h. 174. pula bahwa cara tersebut sangat tepat untuk membina mental remaja. Dalam proses ini tersimpul bahwa pembinaan akhlak merupakan panutan bagi umat manusia untuk memiliki sikap mental dan kepribadian baik yang ditunjukkan oleh AlQur'an dan Al-Hadis Nabi Muhammad SAW, pembinaan, pendidikan dan penanaman nilainilai akhlakul karimah sangat tepat bagi anak agar didalam perkembangan mentalnya tidak mengalami hambatan dan penyimpangan kearah negatif. ${ }^{30}$

d. Aspek Sosial Kemasyarakatan Tujuan dari pendidikan sosial kemasyarakatan seorang anak adalah agar anak mampu beradaptasi dengan lingkungan kemasyarakatannya, dengan orang-orang yang lebih dewasa atau dengan teman-teman yang sebaya dan juga agar ia bisa mempunyai peran yang positif. Demikian juga agar ia terhindar dari sifat memikirkan diri sendiri dan rasa malu yang tidak pada tempatnya. Ia akan menerima dan memberi dengan tatakrama berjual beli dan juga melakukan interaksi sosial. ${ }^{31}$

4. Materi Pendidikan Islam

Ada beberapa pendapat ulama tentang materi yang harus diberikan terhadap anak

30 Sudarsono, Etika Islam tentang Kenakalan Remaja, Jakarta: Bina Aksara, Cet2, 1991, h. 151.

31 Muhammad Suwaid, Mendidik Anak Brsama Nabi, h. 202. 
didik, yang dikutip oleh Armai Arief dalam bukunya antara lain adalah:

a. Menurut Umar bin Khattab, seorang anak hendaknya diajarkan berenang, berkuda, pepatah yang berlaku dan sajak-sajak yang terbaik. Semua ini diajarkan setelah anak mengetahui prinsipprinsip agama Islam, menghafal Al-Qur'an dan mempelajari Hadis.

b. Ibnu Sina mengemukakan, bahwa pendidikan anak hendaknya dimulai dengan pelajaran Al-Qur'an. Kemudian diajarkan syairsyair pendek yang berisi tentang kesopanan setelah anak selesai menghafal AlQur'andan mengerti tata bahasa Arab disamping diberi petunjuk dan bimbingan agar mereka dapat mengamalkan ilmunya sesuai dengan bakat dan kesediannya.

c. Abu Thawam berpendapat, setelah anak hafal Al-Qur'an hendaknya anak tersebut diajarkan menulis, berhitung dan berenang.

d. Al-Ghazali mengemukakan, bahwa sebaiknya anak-anak diajarkan Al-Qur'an, sejarah kehidupan orang-orang besar, hukum-hukum agama dan sajak-sajak yang tidak menyebut soal cinta serta pelaku-pelakunya. e. Al-Jahiz, dalam bukunya "Risalat al-Mu'alimin" mengatakan bahwa sebaiknya anak-anak kecil tidak disibukkan dengan ilmu nahwu semata. Cukup sampai mereka dapat membaca, menulis dan bicara dengan benar. Anakanak seharusnya diberikan pelajaran berhitung karang mengarang serta keterampilan membaca buah pikiran dari bacaannya. ${ }^{32}$

Pendapat para ulama diatas, dapat difahami bahwa materi pendidikan agama Islam yang paling utama adalah Al-Qur'an, baik keterampilan membaca, menghafal, menganalisa dan sekaligus mengamalkan ajaran-ajaran yang terkandung didalamnya dalam kehidupan sehari-hari. Hal inidimaksudkan agar ajaran yang terkandung di dalam Al-Qur'an tertanam dalam jiwa anak didik sejak dini.

5. Kurikulum Pendidikan Agama Islam a. Pengertian Kurikulum

Kata "kurikulum" berasal dari bahasa Yunani yang semula digunakan dalam bidang olah raga, yaitu currere yang berarti jarak tempuh lari, yakni jarak yang harus ditempuh dalam kegiatan berlari mulai dari start hingga finish.Pengertian ini kemudian

32 Armai Arief, Pengantar Ilmu dan MetodologiPendidikan Islam, Jakarta: Ciputat Pers, Cet-1, 2002, h. 30-31. 
digunakan dalam diterapkan dalam bidang pendidikan. Dalam bahasa Arab, istilah "kurikulum" diartikan dengan Manhaj, yakni jalan yang terang, atau jalan terang yang dilalui oleh manusia pada bidang kehidupannya. Dalam konteks pendidikan, kurikulum berarti jalan terang yang dilalui oleh pendidik/guru dengan peserta didik untuk mengembangkan pengetahuan, keterampilan dan sikap serta nilai-nilai. $^{33}$

Pengertian yang lain tentang kurikulum disebutkan oleh Ahmad Tafsir dalam bukunya Abuddin Nata, bahwa kurikulum tidak hanya sekedar berisi rencana pelajaran atau bidang studi, melainkan semua yang secara nyata terjadi dalam proses pendidikan di sekolah. ${ }^{34}$

\section{B. Metode Pembelajaran}

1. Pengertian Metode

Metode mengajar adalah cara yang digunakan oleh guru untuk menyampaikan pelajaran kepada pelajar. Karena penyampaian itu berlangsung dalam interaksi edukatif, metode mengajar dapat diartikan sebagai cara yang dipergunakan oleh guru dalam

33 Muhaimin, Pengembangan Kurikulum Pendidikan Agama Islam (di Sekolah, Madrasah, dan Perguruan Tinggi), Jakarta: Raja Grafindo Persada, Cet-4, 2010, h.1.

34 Abuddin Nata, Ilmu Pendidikan Islam, Jakarta: Kencana Prenada Media Group, Cet-1, 2010, h. 124. mengadakan hubungan dengan pelajar pada saat berlangsungnya pengajaran ${ }^{35}$

Menurut Mohammad Athiyah Al-Ab-rasi dalam Ramayulis dan Samsyul Nizar, mendefinisikan bahwa metode adalah, jalan yang digunakan oleh pendidik untuk memberikan pengertian kepada peserta didik tentang segala macam materi dalam berbagai proses pembelajaran. ${ }^{36}$

Dalam bahasa Arab, metode dikenal dengan istilah thariqahyang berarti langkahlangkah strategis dipersiapkan untuk melakukan suatu pekerjaan. Bila dihubungkan dengan pendidikan, maka strategi tersebut haruslah diwujudkan dalam proses pendidikan, dalam rangka pengembangan sikap mental dan kepribadian agar peserta didik mampu menerima pelajaran dengan mudah, efektif dan dapat dicerna dengan baik, sementara dalam pendangan filisofis pendidikan, metode merupakan alat yang dipergunakan untuk mencapai tujuan pendidikan. ${ }^{37}$

2. Faktor-faktor yang Perlu Diperhatikan dalam Memilih Metode Pengajaran, yaitu :

1. Tujuan yang hendak dicapai

35 Departemen Agama Republik Indonesia, Metodologi Pendidikan Agama Islam, Jakarta :Direktorat Jendral Pembinaan Kelembagaan Agama Islam, 2001, h. 88.

36 Ramayulis dan Syamsul Nizar, Filsafat Pendidikan Islam ,Jakarta: Kalam Mulia, 2009. h. 214.

${ }^{37}$ Ibid. 
2. Kemampuan guru

3. Anak didik

4. Situasi dan kondisi pengajaran dimana berlangsung

5. Fasilitas yang tersedia

6. Waktu yang tersedia

7. Kebaikan dan kekurangan sebuah metode. ${ }^{38}$

3. Kedudukan Metode dalam Belajar Mengajar

Salah satu usaha yang tidak pernah guru tinggalkan adalah bagaimana memahami kedudukan metode sebagai salah satu komponen yang ikut ambil bagian bagi keberhasilan kegiatan belajar mengajar, antara lain adalah:

a. Metode Sebagai Alat Motivasi Ekstrinsik

Motivasi Ekstrinsik adalah motif-motif yang aktif dan berfungsinya karena adanya perangsang dari luar. Karena itu, metode berfungsi sebagai alat perangsang dari luar yang dapat membangkitkan belajar seseorang.

b. Metode Sebagai Strategi Pengajaran

Mengingat daya serap anak didik berbeda-beda, ada yang cepat ada yang sedang dan ada yang lambat, faktor inteligensi yang mempengaruhi daya serap seorang anak, maka guru harus memiliki strategi agar anak didik dapat belajar secara efektif dan efisien, mengena pada tujuan yang diharapkan. Salah satu langkah untuk memilih strategi itu adalah harus menguasai teknik-teknik penyajian atau metode mengajar.

c. Metode Sebagai Alat untuk Mencapai Tujuan

Tujuan dari kegiatan belajar mengajar tidak akan pernah tercapai selama komponenkomponen lainnya tidak diperlukan. Salah satunya adalah komponen metode. Metode adalah salah satu alat untuk mencapai tujuan. Dengan memanfaatkan metode secara akurat guru akan mampu mencapai tujuan pengajaran. Ketika tujuan dirumuskan agar anak didik memiliki keterampilan tertentu, maka metode yang digunakan harus disesuaikan dengan tujuan. ${ }^{39}$

4. Dasar Metode Pendidikan Islam Dalam penerapannya, metode pendidikan Islam menyangkut permasalahan individual atau sosial peserta didik dan pendidik itu sendiri. Untuk itu dalam menggunakan metode seorang pendidik harus memperhatikan dasar-dasar umum metode pendidikan Islam.
38 Armai Arief, Pengantar Ilmu dan Metodologi Pendidikan Islam, Jakarta : Ciputat Pers, Cet-1, 2002, h. 109.
39 Syaiful Bahri Djamarah dan Aswan Zain, Strategi Belajar Mengajar, Jakarta: Rineka Cipta, 2002, h. 82-84. 
Dasar -dasar tersebut antara lain adalah:

a. Dasar Agamis.

Al-Qur' an dan Al-Hadis tidak bisa dilepaskan dari pelaksanaan metode pendidikan Islam, karena dalam kedudukannya sebagai dasar ajaran Islam, maka dengan sendirinya metode pendidikan Islam harus merujuk pada kedua sumber ajaran tersebut.

b. Dasar Biologis

Perkembangan biologis manusia mempunyai pengaruh dalam perkembangan intelektualnya. Semakin dinamis perkembangan biologis seseorang, maka dengan sendirinya makin meningkat pula daya intelektualnya.

c. Dasar Psikologis

Metode pendidikan Islam akan dapat diterapkan secara efektif bila didasarkan pada perkembangan dan kondisi psikologis peserta didiknya. Sebab, perkembangan dan kondisi psikologis peserta didik akan memberikan pengaruh yang sangat besar terhadap penerimaan nilai pendidikan dan pengetahuan yang dilaksanakan. Dalam kondisi yang labil (jiwa yang tidak normal), pemberian ilmu pengetahuan dan internalisasi nilai akan berjalan tidak sesuai dengan yang diharapkan.

d. Dasar Sosiologis
Interaksi yang terjadi antara sesama peserta didik dan interaksi antara sesama peserta didik, merupakan interaksi timbal balik dan saling memberikan dampak pada keduanya. Sehingga seorang pendidik harus memberikan ketauladanan dalam bersosiologi dengan pihak lain, seperti dengan peserta didik, sesama pendidik, karyawan, dan kepala sekolah. ${ }^{40}$

5. Metode-metode Pembelajaran Agama Islam

Ada bermacam-macam metode yang dapat digunakan oleh seorang guru dalammenyampaikan materi pelajaran kepada siswa dalam rangka mencapai tujuan pembelajaran, metode-metode itu antara lain sebagai berikut :

a. Metode Pembiasaan

Pembiasaan secara etimologi berasal dari kata "biasa", Dalam Kamus Besar Bahasa Indonesia "biasa" adalah 1). Lazim atau umum, 2). Seperti sedia kala, 3). Sudah merupakan hal yang tidak terpisahkan dari kehidupan sehari-hari. Dengan adanya prefix "pe" dan sufiks "an" menunjukkan arti proses membuat sesuatu atau orang menjadi terbiasa. 
b. Metode Keteladanan

Keteladanan adalah halhal yang dapat ditiru atau dicontoh. Dalam bahasa Arab "keteladanan" diungkapkan dengan kata "uswah" , yang terbentuk dari huruf-huruf : hamzah, as-sin, dan al-waw. Secara etimologi setiap kata dalam bahasa Arab yang terbentuk dari ketiga huruf tersebut memiliki persamaan arti yaitu "pengobatan dan perbaikan".

c. Metode Pemberian Ganjaran dan Hukuman

Ganjaran adalah alat pendidikan preventif dan represif yang menyenangkan dan bisa menjadi pendorong atau motivator belajar bagi murid.

Sedangkan hukuman adalah alat pendidikan preventif dan represif yang paling tidak menyenangkan, karena merupakan imbalan dari perbuatan yang tidak baik dari peserta didik. ${ }^{41}$

d. Metode Ceramah

Metode ceramah adalah suatu metode didalam pendidikan diamana cara penyampaian materi-materi pelajaran kepada anak didik dilakukan dengan cara

41 Armai Arief, Pengantar Ilmu dan Metodologi Pendidikan Islam, h. 110-129. penerangan dan penuturan secara lisan.

e. Metode Tanya Jawab

Metode Tanya Jawab adalah sebuah metode didalam pendidikan dimana guru bertanya sedangkan murid menjawab tentang materi yang ingin diperolehnya.

f. Metode Demonstrasi

Metode demonstrasi adalah cara penyajian bahan pelajaran dengan meragakan atau mempertunjukkan kepada siswa suatu proses, situasi, atau benda tertentu yang sedang dipelajari, baik sebenarnya atau tiruan, yang sering disertai dengan penjelasan lisan.

g. Metode Karyawisata

Teknik ini adalah cara mengajar yang dilaksanakan dengan mengajar dengan mengajak siswa ke suatu tempat atau objek tertentu di luar sekolah untuk mempelajari/menyelididki sesuatu seperti meninjau pabrik sepatu, suatu bengkel mobil, toko serba ada, suatu peternakan atau perkebunan, museum dan sebagainya.

h. Metode Diskusi

Metode diskusi adalah cara penyajian pelajaran, dimana siswa-siswa dihadapkan kepada suatu 
masalah yang bisa berupa pernyataan atau pertanyaan yang bersifat problematis untuk dibahas dan dipecahkan bersama.

Teknik diskusi adalah salah satu teknik belajar mengajar yang dilakukan oleh seorang guru di sekolah. Di dalam diskusi ini proses belajar mengajar terjadi, dimana interaksi antara dua atau lebih individu yang terlibat, saling tukar menukar pengalaman, informasi, memecahkan masalah, dapat terjadi juga semuanya aktif, tidak ada yang pasif sebagai pendengar saja.

i. Metode Eksperimen

Metode eksperimen (percobaan) adalah cara peenyajian pelajaran, di mana siswa melakukan percobaan dengan mengalami dan membuktikan sendiri sesuatu yang dipelajari. Dalam proses belajar mengajar dengan metode percobaan ini siswa diberi kesempatan untuk mengalami sendiri, mengikuti suatu proses, mengamati suatu objek, menganalisis, membuktikan dan menarik kesimpulan sendiri mengenai suatu objek, keadaan atau proses sesuatu. j. Metode Latihan

Metode latihan yang disebut juga metode trainingmerupakan suatu cara mengajar yang baik untuk menanamkan kebiasaan-kebiasaan tertentu, juga sebagai sarana untuk memelihara kebiasaan-kebiasaan yang baik. Selain itu, metode dapat juga digunakan untuk memperoleh suatu ketangkasan, ketepatan dan keterampilan. ${ }^{42}$

\section{PEMBAHASAN}

Pendidik adalah orang dewasa yang bertanggung jawab memberikan pertolongan pada peserta didiknya dalam perkembangan jasmani dan rohaninya, agar mencapai tingkat kedewasaannya, mampu berdiri sendiri dan memenuhi tugasnya sebagai hamba dan khalifah Allah SWT, dan mampu melakukan tugasnya sebagai makhluk sosial dan sebagai mahluk individu yang mandiri.

Pendidik mencakup pula guru, dosen dan guru besar. Guru adalah pendidik profesional yang tugas utamanya mendidik, mengajar, membimbing, mengarahkan, melatih, menilai dan mengevaluasi peserta didik pada pendidikan anak

42 Syaiful Bahri Djamarah dan Aswan Zain, Startegi Belajar Mengajar, Jakarta: Rineka Cipta, Cet-2, 2002, h. 99-109. 
usia dini jalur pendidikan formal, pendidikan dasar dan pendidikan menengah. Dalam hal ini dapat dikatakan bahwa guru bukan hanya sebagai seorang yang memiliki tugas mengajar, tetapi juga dikatakan sebagai seorang pendidik, khususnya pada tingkat Sekolah Dasar, bahwa guru lebih tepat disebut sebagai seorang pendidik bagi siswa-siswanya yang masih pada taraf pendidikan dasar.

Berdasarkan uraian dan pernyataan tersebut di atas, bahwa yang dimaksud dengan pendidik ialah tenaga profesional yang diserahi tugas dan tanggung jawab untuk menumbuhkan, membina, mengembangkan bakat, minat, kecerdasan, akhlak, moral, pengalaman, wawasan dan keterampilan peserta didik.

Berkaitan dengan hal tersebut, ada ketentuan tentang syarat-syarat yang harus dipenuhi untuk menjadi seorang pendidik profesional. Kedudukan guru sebagai tenaga profesional sebagaimana dimaksud dalam pasal 2 ayat (1) Undang-Undang No. 14 Tahun 2005 tentang Guru dan Dosen, adalah berfungsi untuk meningkatkan mutu pendidikan nasional.

Kedudukan guru sebagai tenaga profesional bertujuan untuk melaksanakan sistem pendidikan nasional dan mewujudkan tujuan pendidikan nasional, yaitu berkembangnya potensi peserta didik agar menjadi manusia yang beriman dan bertaqwa kepada Tuhan Yang Maha Esa, berakhlak mulia, sehat, berilmu, cakap, kreatif, mandiri dan menjadi warga negara yang demokratis dan bertanggung jawab, maka dari itu, seorang guru atau pendidik juga harus memenuhi kualifikasi tentang keguruan yang dapat menunjang keberhasilan dalam melaksanakan tugasnya dalam sebuah proses pembelajaran sehingga guru dapat memililki kemampuan dan kewenangan dalam menjalankan profesi keguruan dengan segala kemampuan yang dimiliknya $^{43}$

$$
\text { Kepala }
$$

Muhammadiyah Metro Pusat dalam wawancara dengan peneliti mengemukakan kualifikasi yang harus dipenuhi seorang guru dalam rangka mewujudkan tujuan pendidikan nasional, dan berkaitan dengan tugas keprofesionalan seorang guru, mereka harus pula memiliki kompetensi sebagai berikut:

a. Kompetensi pedagogik terkait dengan kesungguhan dalam mempersiapkan pembelajaran atau perkuliahan, keteraturan dan ketertiban dalam menyelenggarakan

pembelajaran, kemampuan mengelola kelas, kedisplinan dan kepatuhan terhadap aturan akademik, penguasaan media dan teknologi pembelajaran, kemampuan melaksanakan penilaian prestasi belajar peserta

${ }^{43}$ Rubuiah Astutih. 
didik, objektivitas dalam penilaian terhadap peserta didik dan berpersepsi positif terhadap kemampuan mahasiswa.

b. Kompetensi profesional meliputi penguasaan bidang keahlian yang menjadi tugas pokoknya, keluasan wawasan keilmuan, kemampuan menunjukkan keterkaitan antara bidang keahlian yang diajarkan dan konteks kehidupan, penguasaan terhadap isu-isu mutakhir dalam bidang yang diajarkan, kesediaan melakukan refleksi dan diskusi permasalahan pembelajaran, pelibatan mahasiswa dalam penelitian, kajian atau pengembangan, rekayasa dan desain yang dilakukan dosen, kemampuan mengikuti perkembangan ilmu pengetahuan dan teknologi untuk pemutakhiran pembelajaran, dan keterlibatan dalam kegiatan ilmiah organisasi profesi.

c. Kompetensi kepribadian meliputi kewibawaan sebagai pribadi pendidik, kearifan dalam mengambil keputusan, menjadi contoh dalam bersikap dan berperilaku, satunya kata dan perbuatan, kemampuan mengendalikan diri dalam berbagai situasi dan kondisi serta adil dalam memperlakukan teman sejawat.

d. Kompetensi sosial meliputi kemampuan menyampaikan pendapat, kemampuan menerima kritik, saran, dan pendapat orang lain, mudah bergaul dengan kalangan sejawat, karyawan dan peserta didik, serta toleran terhadap keseragaman (pluralisme) di masyarakat. ${ }^{44}$

Selain keempat kompetensi yang harus dimiliki oleh seorang guru sebagaimana di atas, ada kompetensi-kompetensi lain yang harus dimiliki juga oleh guru dalam melaksanakan tugasnya sebagai pendidik dalam proses pembelajaran. Sepuluh kompetensi guru ini merupakan profil kemampuan dasar bagi seorang guru dalam melaksanakan peranannya secara bertanggung jawab dalam kegiatan pembelajaran di kelas. Kompetensi guru ini sangat menunjang efektifitas dalam melaksanakan tugasnya, yakni sebagai berikut:

a. Kompetensi dalam menguasai bahan pelajaran

Seorang guru harus
sudah menguasai bahan
pelajaran sebelum ia masuk
kelas untuk menjalani proses
pembelajaran.
menguasai bahan pelajaran
seorang guru akan lebih mudah
menyampaikan materi secara
efektif dan efisien, selain itu
guru juga sudah harus sudah
mempersiapkan bahan-bahan
apa saja yang dapat mendukung
proses pembelajaran sebagai

${ }^{4}$ Abuddin Nata, Ilmu Pendidikan Islam, Jakarta: Kencana Prenada Media Grup, Cet-1, 2010, h.167. 
bahan pengkayaan atas materi yang akan disampaikan.

b. Kompetensi dalam mengelola program pembelajaran

Kemampuan dalam hal ini diawali dengan penyusunan Rencana Pelaksanaan Pembelajaran (RPP). Setiap guru harus mampu menyusun RPP sebagai dasar perencanaan dalam melaksanakan kegiatan pembelajran, dengan adanya RPP maka kegiatan pembelajaran akan dapat dilaksanakan secara tertib dan berurutan.

c. Kemampuan mengelola kelas Untuk mengajar mampu memgelola kelas, yakni menyediakan kondisi yang kondusif untuk berlangsungnya proses belajar mengajar. Kalau belum kondusif, guru harus berusaha seoptimal mungkin untuk membenahinya. Oleh karena itu, kegiatan mengelola kelas akan menyangkut "mengatur tata ruang kelas yang memadai untuk pengajaran" dan "menciptakan iklim belajar mengajar yang serasi". 45

d. Kemampuan menggunakan media atau sumber belajar

45 Sardiman, Interaksi dan Motivasi Belajar Mengajar, Jakarta: Raja Grafindo Persada, 2012, h. 169.
Penggunaan media atau sumber belajar adalah salah satu kemampuan seorang guru dalam menetapkan metode dalam sebuah pembelajaran, dimana seorang guru menyelaraskan antara materi apa yang akan disampaikan, dan materi tersebut disampaikan dengan metode apa lalu kemudian media apa yang dapat digunakan dalam rangka memudahkan siswa untuk memahaminya.

e. Kemampuan melakukan evaluasi pada siswa

Tahapan-tahapan

evaluasi tersebut memiliki tujuan dan fungsinya masingmasing, yaitu sebagai berikut:

1. Ulangan Harian

2. UTS (Ujian Tengah Semester)

3. Ulangan Semester

4. Ujian Akhir Sekolah

Pelaksanaan Ujian

Akhir Sekolah ini sebagai bentuk evaluasi pendidikan yang mesti dilaksanakan oleh sekolah yang bertujuan untuk menentukan layak atau tidaknya seorang siswa untuk dinyatakan lulus dari sebuah lembaga pendiidkan.

f. Melaksanakan Program Bimbingan dan Konseling

Bimbingan adalah proses pemberian bantuan yang diberikan kepada seseorang atau sekelompok orang secara 
terus menerus dan sistematis oleh pembimbing agar individu atau sekelompok individu menjadi pribadi yang mandiri. ${ }^{46}$

Konseling adalah adalah satu jenis pelayanan yang merupakan bagian terpadu dari sebuah bimbingan. Konseling dapat diartikan sebagai hubungan timbal balik antara dua orang individu, dimana yang seorang (yaitu konselor) berusaha membantu yang lain (yaitu konseli) untuk mencapai pengertian tentang dirinya sendiri dalam hubungan dengan masalah-masalah yang dihadapinya pada waktu yang akan datang. ${ }^{47}$

g. Menyelenggarakan Administrasi Sekolah

Salah satu tujuan administrasi sekolah bagi guru adalah agar setiap kegiatan yang dilaksanakan itu tercataat secara tertib dan rapi untuk memudahkan dalam melaporkan

pertanggungjawaban pada kepala sekolah atau kepada orang tua wali.

\section{Implementasi Pembelajaran Pendidikan Agama Islam di Sekolah Dasar(SD) Muhammadiyah Metro Pusat.}

46 Dewa Ketut Sukardi dkk, Proses Bimbingan dan Konseling Di Sekolah, Jakarta: Rineka Cipta, 2008, h. 2

47 Ibid; ,h. 4-5.
Dalam sebuah pembelajaran tidak semua anak didik mampu berkonsentrasi dalam waktu yang relatif lama. Daya serap anak didik terhadap bahan atau materi yang diberikan juga bermacammacam ada yang cepat, ada yang sedang, dan ada yang lambat. Faktor intelegensi mempengaruhi daya serap anak didik terhadap bahan atau materi yang disampaikan oleh seorang guru.

Metode pembelajaran merupakan bagian dari sebuah strategi yang digunakan oleh seorang guru Pendidikan Agama Islam untuk mencapai tujuan yang diharapkan, sehingga dapat dikelompokkan komponen-komponen strategi pembelajaran sebagai berikut:

a. Komponen Urutan Kegiatan Pembelajaran

Mengurutkan kegiatan pembelajaran memudahkan seorang guru dalam melaksanakan kegiatan pembelajaran, yakni cara memulainya, menyajikannya, dan menutup pelajaran, urutan dalam kegiatan pembelajaran ini adalah:

1) Pendahuluan

Hal-hal yang dilakukan
pada tahap ini adalah
memberikan gambaran singkat
tentang isi pelajaran,
menjelaskan ketertkaitan


materi dengan pengalaman siswa serta menjelaskan tentang tujuan pembelajaran.

2) Penyajian

Kegiatan ini merupakan kegiatan inti dari kegiatan pembelajaran. Dalam kegiatan ini siswa atau peserta didik akan ditanamkan pengetahuan baru dan mengembangkan pengetahuan yang telah dimilikinya, tahap-tahapnya adalah menjelaskan materi pelajaran, memberikan contoh, dan memberikan latihan yang sesuai dengan materi pelajaran.

3) Penutup

Kegiatan ini merupakan bagian akhir dalam urutan kegiatan pembelajaran, pada kegiatan ini dimaksudkan untuk memberikan penegasan atau kesimpulan dan penilaian terhadap penguasaan materi yang telah disampaikan.

b. Komponen Metode Pembelajaran

Metode pembelajaran adalah cara yang digunakan oleh seorang guru dalam menyampaikan materi pelajaran terhadap peserta didik agar tujuan pembelajaran dapat tercapai. Seorang guru harus mampu memilih dan menggunakan metode-metode pembelajaran yang disesuaikan dengan materi yang akan disampaikan dan karakteristik peserta didik.
Metode-metode

pembelajaran yang digunakan oleh guru bidang studi Pendidikan Agama Islam di SD Muhammaduyah Metro Pusat antara lain adalah:

\section{Metode Ceramah}

Metode ceramah adalah suatu metode di dalam pendidikan dimana cara penyampaian materi-materi pelajaran kepada anak didik dilakukan dengan cara penerangan dan penuturan secara lisan.

Metode ceramah merupakan metode penyampaian materi pelajaran dengan bercerita secara panjang lebar (tetapi tetap pada kontent atau isi materi ajar) serta menjelaskan relevansi antara materi yang disampikan dengan pengalaman siswa sehari-hari dan kenyataan yang terjadi dikehidupan, metode ini sederhana tetapi memerlukan tenaga serta pemikiran yang cukup karena materi yang disampaikan haruslah disampaikan dengan jelas dan dapat difahami oleh siswa, bahkan diharapkan siswa dapat menerapkannya di kehidupan sehari-hari.

2. Metode Diskusi

Metode ini digunakan untuk melatih siswa dalam memecahkan permaslahan 
yang mereka hadapi dan bekerja secara tim atau kelompok. Dengan menggunakan metode ini seorang guru dapat mengetahui siswa-siswa yang sudah faham dengan materi yang disampaikan dan yang belum. Pada kegiatan ini biasanya seorang guru menyajikan sebuah masalah yang berkaitan dengan materi kemudian siswa diminta untuk mendiskusikannya sampai menemukan pemecahan masalah sesuai dengan kemampuannya.

3. Metode Demonstrasi

Metode demonstrasi digunakan untuk memudahkan dalam menjelaskan suatu contoh yang ada didalam materi pelajaran agar siswa dapat lebih jelas dan paham, misalnya contoh-contoh gerakan sholat dalam materi "shalat sunnah". Metode demonstrasi ini maksudnya adalah guru menggunakan bantuan LCD untuk mendemonstrasikan contoh gerakan shalat kepada siswa, dengan harapan siswa dapat lebih mudah dalam memahaminya, baru kemudian siswa diminta untuk mempraktekkan secara bergantian.

c. Komponen Media yang digunakan Media adalah segala
bentuk dan salauran yang digunakan untuk menyampaikan pesan atau informasi pembelajaran. Media dapat berbentuk orang atau guru, alatalat elektronik, media cetak, media audio, audio visual dan sebagainya. Hal-hal yang harus dipertimbangkan saat memilih media pembelajaran adalah:

1. Ketepatan dengan tujuan pembelajaran

2. Dukungan terhadap isi pelajaran

3. Kemudahan memperoleh media

4. Keterampilan guru dalam menggunakannya

5. Ketersediaan waktu dalam menggunakannya

6. Sesuai dengan taraf berfikir peserta didik.

Media penting dipakai untuk dapat membangkitkan semangat belajar siswa karena dimungkinkan penggunaan media akan lebih menarik seperti pemakaian LCD dalam menjelaskan materi tertentu. ${ }^{48}$

\section{LCD (Liquid Cristal}

Display), yang dapat dipakai sebagai media pembelajaran. Selain itu jaringan internet juga cukup baik sehingga dapat dimanfaatkan ketika guru memberikan tugas yang berkaitan dengan pelajaran Agama Islam dengan menggunakan fasilitas 
internet dengan pengawasan dari guru. 49

d. Komponen Waktu Tatap Muka Seorang guru harus memanfaatkan alokasi waktu yang sudah ada untuk dapat menyelesaikan materi pembelajaran dengan tepat sehingga proses pembelajaran berjalan sesuai dengan target yang ingin dicapai.

e. Komponen Pengelolaan Kelas

Pengelolaan kelas adalah berbagai usaha guru untuk menciptakan dan mempertahankan kondisi kelas yang optimal sehingga terjadi proses pembelajaran yang efektif dan efisien. Hal ini dapat terjadi apabila kondisi kelas mendukung dan kondusif.

Suasana kelas yang
kondusif akan mampu menghantarkan pada prestasi akademik dan nonakademik siswa, kelas yang kondusif memiliki ciri-ciri : tenang, tertib, suasana saling menghargai, saling mendorong, kreativitas tinggi, persaudaraan yang kuat, saling berinteraksi dengan baik, dan bersaing sehat untuk kemajuan. Artinya, kelas dapat diciptakan dan berperan sebagai sumber belajar.

f.Komponen Evaluasi

Seperti yang telah dijelaskan pada pembahasan

49 Hasil Observasi di SD

Muhammadiyah mulai tanggal 3 Februari s/d 28 Maret 2018. sebelumnya, bahwa evaluasi merupakan proses penilaian yang dilakukan dalam rangka untuk mengetahui apakah seorang guru perlu memperbaiki proses pembelajaran agar lebih baik dan agar materi bisa lebih mudah dipahami oleh siswa, sehingga dapat dikatakan bahwa penilaian dapat dijadikan alat ukur keberhasilan atas tercapaianya sebuah kompetensi yang diharapkan dari setiap peserta didik.

Penilaian atau evaluasi yang dilaksanakan oleh guru Pendidikan Agama Islam di SD Muhammadiyah Metro Pusat meliputi empat jenis penilaian, yaitu: Ulangan Harian, UTS, Ulangan Semester dan Ujian Akhir Sekolah.

Selain penilaian yang dilakukan dengan cara tes tertulis, pada mata pelajaran Pendidikan Agama Islam terdapat penilaian atau evaluasi yang dilakukan secara praktek pada materimateri tertentu, serta penilaian pada aspek prilaku serta kebiasaan siswa sehari-hari, penilaian-penilaian tersebut dilakukan dengan tujuan untuk melihat secara langsung apakah siswa sudah benarbenar mengerjakan pekerjaan tersebut dengan benar dan 
sesuai dengan apa yang menjadi standar penilaian yang diharapkan oleh sekolah ataukah belum. Berikut ini adalah contoh penilaian atau spesifikasi ujian praktek Pendidikan Agama Islam yang dilaksanakan oleh guru PAI di SD Muhammadiyah Metro Pusat.

\section{Faktor Pendukung dan}

Penghambat Implementasi

Pembelajaran Agama Islam di SD

Muhammadiyah Metro Pusat. Implementasi

pembelajaran Pendidikan Agama Islam di SD Muhammadiyah Metro Pusat didukung oleh dua faktor, yaitu faktor pendukung dan penghambat, yaitu:

\section{Faktor Pendukung}

a. Sarana dan prasarana sekolah yang memadai

Dalam melaksanakan proses pembelajaran disekolah diperlukan adanya sarana dan prasarana sebagai penunjang keberhasilan dari proses pembelajaran itu sendiri. SD Muhammadiyah Metro Pusat telah menyediakan sarana dan prasarana yang sangat berperan bagi tercapainya tujuan pembelajaran yang salah satunya bagi implementasi penggunaan metode pembelajaran Pendidikan Agama Islam dengan memanfaatkan teknologi dan informasi di sekolah.
Tidak hanya itu, sarana dan prasarana yang cukup lengkap memungkinkan siswa untuk dapat melaksanakan setiap kegiatan yang diadakan di sekolah secara nyaman karena tempat sudah ada di lingkungan sekolah itu sendiri sehingga guru dapat dengan mudah merealisasikan materimateri yang disampaikan untuk langsung diterapkan di kehidupan sekitar siswa. Implementasi

penggunaan metode pembelajaran Pendidikan Agama Islam yang tidak hanya menekankan pada aspek ketuntasan materi, tetapi lebih kepada aspek pemahaman bagi peserta didik akan dapat terwujud apabila mendapat dukungan dari berbagai pihak di sekolah termasuk juga orang tua.

\section{b. Guru yang profesional} Guru Pendidikan Agama Islam yang memiliki kemampuan akademik yang baik menjadi salah satu faktor pendukung bagi penentu keberhasilan atas implementasi pembelajaran PAI, karena guru memiliki otoritas paling banyak dalam pelaksanaan pembelajaran baik secara teori atau konsep maupun secara praktek. Guru Pendidikan Agama Islam juga dituntut untuk dapat menggunakan alat 
bantu atau media pembelajaran yang tepat untuk membantu tercapainya tujuan yang diharapkan, serta guru juga harus tanggap dengan perubahan zaman, mampu menguasai teknologi untuk menunjang proses pembelajaran agar informasi yang disampaikan tidak ketinggalan zaman.

\section{c. Kegiatan pengembangan karakter}

Faktor pendukung lainnya bagi implementasi pembelajaran Pendidikan Agama Islam dengan baik adalah adanya kegiatan pengembangan karakter siswa yang dilaksanakan di sekolah.

Kegiatan-kegiatan yang dilaksanakan di sekolah ini sangat membantu implementasi pembelajaran Pendidikan Agama Islam, salah satunya adalah sikap sopan santun siswa yang mana akan terwujud ketika guru sedang menjelaskan materi pelajaran dengan berceramah, siswa akan mendengarkan dengan seksama dan tidak membuat kegaduhan di dalam kelas. Selain itu kegiatan shalat, penjelasan dari guru dan penyajian contoh melalui LCD (Liquid Cristal Display), akan dengan mudah difahami karena setiap harinya mereka diajak untuk melaksanakan ibadah shalat baik sunnah maupun wajib.

\section{Faktor Penghambat}

\section{a. Sumber belajar yang terbatas}

Salah satu yang menjadi faktor penghambat implementasi pembelajaran Pendidikan Agama Islam adalah sumber belajar yang terbatas. Sumber yang paling banyak digunakan hanya berasal dari buku paket yang diterbitkan oleh PC Muhammadiyah Metro, meskipun ada beberapa buku sumber lain tetapi materi hanya boleh mengacu pada buku yang sudah ditetapkan khususnya pada pelajaran Pendidikan Agama Islam. Hal ini menjadikan guru terbatas ruang geraknya dalam hal perluasan materi karena minimnya sumber belajar yang berupa buku pelajaran.

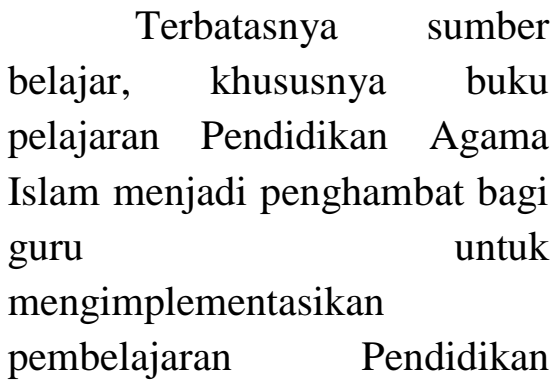
Agama Islam yang bervariasi. Seharusnya sumber belajar bisa diperoleh dari beberapa hal, tidak hanya buku yang sudah ada. Untuk memperkaya wawasan anak didik dan menjadikan mereka mampu berkompetensi dengan 
kemajuan zaman, maka seharusnya sumber belajar yang dipakai dalam rangka mencapai tujuan pembelajaran tidak hanya buku, tetapi haruslah lebih luas lagi seperti memanfaatkan alam atau memanfaatkan teknologi yang sudah sangat maju dengan pesat.

\section{b. Motivasi siswa yang masih kurang}

Faktor lain yang menjadi penghambat dari implementasi penggunaan metode pembelajaran Pendidikan Agama Islam adalah kurangnya motivasi yang dimiliki oleh siswa. Rendahnya motivasi belajar ini menjadikan materi pelajaran mereka tidak tuntas sebagaimana yang direncanakan oleh guru.

Keadaan seperti ini jelas menjadi penghambat seorang guru dalam menyampaikan materi pelajaran, metode apapun yang diapakai akan sulit membuat mereka memahami materi yang disampaikan karena memang motivasi belajar yang masih kurang.

Melihat penjelasan di atas, maka dapat diketahui bahwa kunci keberhasilan dari implementasi pembelajaran Pendidikan Agama Islam pada setiap jenjang pendidikan dalam rangka tercapainya tujuan pendidikan tidak hanya berasal dari guru maupun alat yang dipakai dalam menjelaskan materi pelajaran, tetapi juga dari siswa itu sendiri, bila mereka ingin belajar dengan sungguhsungguh, maka metode apapun yang dugunakan akan mudah untuk difahami dan diterima oleh siswa.

Berdasarkan

hasil pengumpulan data yang dilakukan melalui wawancara dan observasi, maka diperoleh data bahwa:

1. Perencanaan, pelaksanaan dan evaluasi Pembelajaran Pendidikan Agama Islam di SD Muhammadiyah Metro Pusat meliputi:

a. Seorang guru yang profesional dalam melaksanakan proses pembelajaran serta dalam rangka mencapai tujuan yang diharapkan haruslah terlebih dahulu mempersiapkan rencana pembelajaran dengan tepat, begitu juga dengan guru Pendidikan Agama Islam yang harus mempersiapkan Rencana Pelaksanaan Pembelajaran (RPP), yang meliputi: kalender pendidikan, program tahunan, program semester, silabus, materi, sampai dengan kegiatan remedial atau evaluasi sebelum seorang guru melaksanakan proses pembelajaran. Seorang guru dituntut untuk memiliki kemampuan dalam hal 


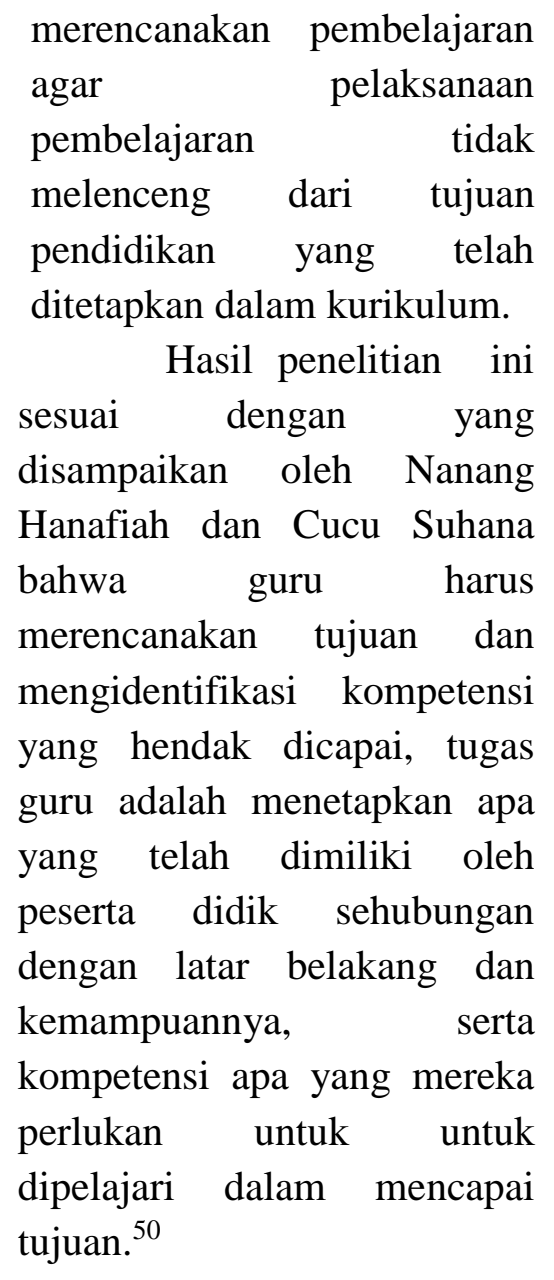

Penelitian ini juga didukung oleh penelitian Ghulam Murtadlo yang berjudul "Model Pembelajaran Pendidikan Agama Islam di SMPN 4 Metro", yang menyatakan bahwa salah satu kompetensi yang harus dimiliki oleh seorang guru adalah kompetensi dalam hal penyusunan rencana pembelajaran. Penyususnan Rencana Pelaksanaan Pembelajaran (RPP) adalah hal mutlak yang harus diketahui dan dilaksanakan oleh setiap guru, karena dengan penyusunan rencana pembelajaran menjadi dasar bagi guru dalam melaksanakan kegiatan pembelajaran. ${ }^{51}$

b. Pembelajaran Pendidikan Agama Islam di SD Muhammadiyah Metro Pusat dalam melaksanakan proses pembelajaran mengacu pada komponen-komponen strategi pembelajaran, hal ini karena metode sebagai sebuah strategi pembelajaran yang memiliki beberapa komponen yang salah satunya adalah komponen Metode Pembelajaran, yang mana metode merupakan salah satu cara yang digunakan guru guna membantu proses pembelajaran menjadi lebih efektif dan efisien. Metode yang paling banyak dipakai oleh guru Pendidikan Islam diantaranya adalah: Metode Ceramah, Metode Diskusi dan Metode Demonstarsi, menyesuaikan dengan keadaan kelas dan kondisi siswa yang ada.

Hal tersebut dikatakan oleh Syaiful Bahri Djamarah dan Aswan Zain dalam bukunya "Strategi 
Belajar Mengajar", bahwa guru harus memiliki strategi agar anak didik dapat belajar secara efektif dan efisien, mengena pada tujuan yang diharapkan. Salah satu langkah untuk memilih startegi itu harus menguasai teknik-teknik penyajian atau biasanya disebut metode mengajar. Dengan demikian, metode mengajar adalah startegi pengajaran sebagai alat untuk mencapai tujuan yang diharapkan. ${ }^{52}$

c. Dalam

proses

pengimplementasian

pembelajaran Pendidikan Agama Islam di SD Muhammadiyah Metro Pusat terdapat faktorfaktor pendukung dan penghambat berjalannya proses pembelajaran di sekolah. Faktor pendukungnya antara lain adalah: sarana dan prasarana sekolah yang memadai, guru yang profesional, kegiatan pengembangan karakter. Adapun faktor penghambatnya adalah: sumber belajar yang terbatas, motivasi siswa yang masih kurang.

Berdasarkan dari hasil analisis data dan pembahasan tersebut di atas, maka dapat disimpulkan bahwa kemampuan atau kompetensi seorang guru

52 Syaiful Bahri Djamarah, Aswan Zain, Strategi Belajar Mengajar, Jakarta: Rineka Cipta, Cet-2, 2002, h. 84. dalam merencanakan, melaksanakan dan mengevaluasi kegiatan pembelajaran sangatlah diperlukan dalam mengimplementasikan sebuah proses pembelajaran Pendidikan Agama Islam dengan baik.

\section{E. KESIMPULAN}

$$
\begin{aligned}
& \text { Berdasarkan } r \text { hasil } \\
& \text { pemaparan data dan hasil } \\
& \text { penelitian, maka diperoleh } \\
& \text { beberapa kesimpulan berikut } \\
& \text { ini: }
\end{aligned}
$$

a. Proses perencanaan dari seorang guru Pendidikan Agama Islam di SD Muhammadiyah Metro Pusat diwujudkan dalam sebuah Rencana Pelaksanaan Pembelajaran (RPP), yang diberi waktu khusus oleh sekolah untuk merumuskannyai melalui kegiatan workshop selama dua hari, kegiatan tersebut untuk mempersiapkan perangkat pembelajaran yang meliputi penyusunan silabus, kalender pendidikan, program tahuanan, program semester, materi ajar sampai dengan kegiatan remedial, dan disyahkan oleh tim supervisi sekolah.

b. Implementasi atau pelaksanaan Pembelajaran Pendidikan Agama Islam di SD Muhammadiyah Metro pusat mengacu pada 
komponen-komponen

strategi pembelajaran, hal ini dikarenakan metode adalah bagian dari sebuah strategi pembelajaran, yang memiliki beberapa komponen, yang salah satunya adalah Komponen Metode Pembelajaran, metode yang paling banyak dipakai oleh guru Pendidikan Agama Islam di SD Muhammadiyah Metro Pusat adalah metode ceramah, metode diskusi, dan metode demonstrasi.

c. Pada proses evaluasi pembelajaran, guru SD Muhammadiyah Metro Pusat melaksanakan proses evaluasi yang antara lain adalah: Ulangan Harian, Ujian Tengah Semester dan Ujian Akhir Semester.

\section{DAFTAR PUSTAKA}

Abuddin Nata, Ilmu Pendidikan Islam, Jakarta: Kencana Prenada Media Grup, Cet-1, 2010.

Armai Arief, Pengantar Ilmu dan Metodologi pendidikan Islam, Jakarta: Ciputat Pres, Cet-1, 2002.

Azyumardi Azra, Pendidikan Islam, tradisi dan modernisasi menuju millennium baru”, Jakarta: Logos, 1999.

Bambang Warsita, Teknologi Pembelajaran landasan dan aplikasinya, Jakarta: Rineka Cipta, 2008.

Departemen Agama Republik Indonesia, Metodologi Pendidikan Agama Islam , Jakarta : Direktorat Jendral Pembinaan Kelembagaan Agama Islam, 2001.

Qur'an dan Tarjamahan, Bandung: Diponegoro.

Dewa Ketut Sukardi, dkk, Proses Bimbingan dan Konseling Di Sekolah, Jakarta: Rineka Cipta, 2008.

Lexy J. Moleong, Metodologi Penelitian Kualitatif, Bandung : PT Remaja Rosda Karya, Cet21, 2005.

Muhaimin, Paradigma Pendidikan Islam, Upaya Mengefektifkan Pendidika Islam di sekolah, Bandung : PT Remaja Rosda Karya, Cet-1, 2001.

Muhaimin dan Abd. Ghofir dan Nur Ali Rahma, Strategi Belajar Mengajar, Surabaya: CV Citra Media, 1996.

M. Uzer Usman, Menjadi Guru Profesional, Bandung: Remaja Rosda Karya, 1995.

M.Ihsan Dacholfany, Inisiasi Strategi Manajemen Lembaga Pendidikan Islam Dalam Meningkatkan Mutu Sumber Daya Manusia Islam di Indonesia Dalam menghadapi Era Globalisasi, Jurnal AtTajdid, Volume 1, No.1 Januari-Juni, 2017 
Omar Muhammad al-Toumy alSyaibany, Falsafah Pendidikan Islam, Jakarta : Bulan Bintang, 1979.

Ramayulis dan Syamsul Nizar, Filsafat Pendidikan Islam, Jakarta: Kalam Mulia, 2009.

Rusman dkk, Pembelajaran Berbasis

Teknologi Informasi dan Komunikasi, mengembangkan profesionelisme Guru, PT Raja Grafindo Persada, Cet-2, 2012. ------------, Belajar dan Pembelajaran Berbasis Komputer, mengembangkan profesionalisme guru abad 21, Bandung: Alfabeta, Cet-1, 2012.

Sardiman, Interaksi dan Motivasi Belajar Mengajar, Jakarta: Raja Grafindo Persada, 2012.

Sugiyono, Memahami Penelitian Kualitatif, Bandung : Alfabeta, Cet-1, 2005.

Sutrisna Hadi, Metodologi Research, Yogyakarta : Fakultas Psikologi UGM, Cet-2, 1980.

Syaiful Bahri Djamarah dan Aswan Zain, Strategi Belajar Mengajar, Jakarta: Rineka Cipta, 2002.

W. Gulo, Metodologi Penelitian, Jakarta : PT Gramedia Widia Sarana, Cet-1, 2002.

Zakiah Darajat dkk, Ilmu Pendidikan Islam, Jakarta: Bumi Aksara, 2008. 